\title{
Social Exclusion and Early or Unwanted Sexual Initiation Among Poor Urban Females in Ethiopia
}

By Annabel Erulkar
and Abebaw
Ferede

Annabel Erulkar is country director, and

Abebaw Ferede is senior program officer, both at the Population Council, Addis Ababa, Ethiopia.

CONTEXT: Numerous studies of adolescent sexual behavior have explored factors associated with early sexual debut. However, few studies have examined the role of social exclusion and marginalization in relation to early and unwanted sexual initiation.

METHODS: A population-based study of 1,837 out-of-school females aged 10-19 was conducted in three low-income urban areas of Ethiopia in 2008. Descriptive and multivariate analyses were used to identify characteristics associated with having experienced coerced sexual initiation and sexual debut before age 15.

RESULTS: Nearly half (48\%) of the young women in the sample were domestic workers, and many reported significant social exclusion, including lack of friends, community support networks and group membership. Overall, 23\% reported being sexually experienced and $27 \%$ of those had first had sex before age 15 . Compared with other young women, domestic workers were significantly more likely to have had sex before age 15 (odds ratio, 3.3), and to have been coerced into having sex (1.8). Social exclusion was associated with significantly higher odds of coerced first sex (2.0).

CONCLUSIONS: Programs for female adolescents should build their social capital and inclusion, as well as provide opportunities for them to stay in school and obtain positive and nonexploitive forms of work.

International Perspectives on Sexual and Reproductive Health, 2009, 35(4):186-193

Interest in the sexual behavior and reproductive health of adolescents in developing countries has increased since the early 1990s. The earliest studies of sexual behavior frequently examined factors associated with sexual experience, particularly individual-level factors, such as school attendance, educational attainment and knowledge of risk factors. ${ }^{1,2}$ Later, research evolved to include broader contextual factors seen as influencing the experience and timing of adolescents' sexual transitions. Connectedness to family, schools, voluntary groups and peer groups, and the social norms governing these groups were also thought to be factors in young people's risk-taking behavior. 3,4

Studies in a variety of settings have demonstrated the association between positive family and peer connections and a decreased likelihood of sexual experience and potentially risky behaviors. ${ }^{4-7}$ For example, in Ghana, parental regulation was inversely associated with the likelihood of young people having sexual experience. ${ }^{7}$ The effect of peer connections on sexual risk behaviors seems to be associated with the characteristics of the peers; adolescents whose friends model healthy behaviors are more likely to engage in those behaviors themselves. ${ }^{4}$ Social participation, as measured by membership in social groups and clubs, has been found to be associated with mainly healthy behaviors and lifestyles among adolescents in a number of settings, though an elevated risk of unhealthy behaviors is associated with membership in certain types of groups. ${ }^{8}$ For example, in one study in South Africa, compared with those who did not, females who belonged to sports clubs were less likely to be HIV-positive and more likely to negotiate protective measures, such as condom use. However, females taking part in local savings clubs that had periodic parties and included male members exhibited higher rates of casual partnerships. ${ }^{9}$ Thus, the norms and culture that govern social groups, rather than just membership in them, seem to influence adolescent behavior. ${ }^{3}$

\section{Social Exclusion and Marginalization}

If positive social connectedness is linked to healthy behaviors in adolescents, then social exclusion and marginalization may be predictive of poor outcomes. Social exclusion is defined as limited or no participation in social, economic and political life. ${ }^{10}$ Adolescent females report having significantly fewer friends than males and experiencing greater control of their movement and social interactions by others. ${ }^{10}$ Emerging evidence suggests that females who are isolated and marginalized may be more susceptible to sexual abuse. In a study in South Africa, females reporting few or no friends were six times as likely to have experienced forced sexual encounters as females reporting "many friends."11

\section{Adolescent Domestic Workers}

One group often considered to be socially excluded and isolated is domestic workers, who are almost exclusively young and female. ${ }^{12,13}$ Domestic work is considered to be among the types of work with the lowest status and the poorest pay, ${ }^{14}$ and the nature of the work keeps females in- 
accessible and socially isolated. ${ }^{13}$ Their workplace is a private residence, and within the domestic sphere, workers frequently work long hours for little pay, with few opportunities for social interaction.

Previous research in low-income areas of Addis Ababa, Ethiopia, found that many poor females were engaged in domestic work, working an average of 64 hours per week and earning an average of 52 birr (US\$6) per month. ${ }^{15}$ Working long hours and being subject to control by their employers left them few opportunities for recreation, socialization or participation in available youth programs and services. ${ }^{15,16}$ Among all categories of child workers, domestic workers are considered to be the most vulnerable to abuse, including physical and sexual violence; ${ }^{12}$ anecdotal evidence and findings from qualitative data suggest that domestic workers may be more susceptible to abuse, both inside and outside the home. ${ }^{15}$ However, survey data provide no evidence that domestic workers experience higher rates of sexual abuse than other females.

\section{Nonconsensual Sexual Initiation}

A growing body of evidence suggests that nonconsensual or coercive sex is a common feature of adolescents' earliest sexual experiences, especially for females. ${ }^{17-19}$ Sexual coercion is defined by Heise and colleagues as "the act of forcing (or attempting to force) another individual through violence, threats, verbal insistence, deception, cultural expectations or economic circumstances to engage in sexual behavior against her will... The touchstone of coercion is an individual woman's lack of choice to pursue other options without severe social or physical consequences." 20 In addition, females who experience coerced or forced sex are more likely than those who do not to experience negative reproductive health outcomes such as STIs, unwanted pregnancies, miscarriage, low-birth-weight babies and depression. ${ }^{18,21,22}$

In Sub-Saharan Africa, estimates of coerced sexual initiation range from $15 \%$ to $40 \%$, perhaps in part because the way in which coercion is defined varies from study to study. ${ }^{17,23,24}$ Most studies of sexual coercion among African adolescents focus on prevalence of nonconsensual sex or negative health or behavioral outcomes. However, few studies explore socioeconomic situations that may make specific subgroups of young women more vulnerable to sexual coercion.

This study explores the role of social exclusion in sexual debut. We examine factors associated with sexual debut that occurs very early (before age 15) and sexual debut that is nonconsensual. The study was undertaken in extremely poor urban settings in Ethiopia, where social isolation and exclusion are considered to be more pronounced. ${ }^{10}$

\section{METHODS}

Data for this study are from a population-based survey undertaken in mid-2008 of out-of-school female adolescents aged 10-19 in three Ethiopian cities. Addis Ababa is Ethiopia's capital, and Bahir Dar and Gondar are cities in the country's second-largest region, Amhara. Located in Ethiopia's northern highlands, Amhara has the highest rate of early marriage in the country and substantial rates of internal migration. ${ }^{25,26}$ Slum areas of these three cities are the destination of many rural-urban migrants, including adolescents coming from rural areas of the country in search of better opportunities or escaping hardship, such as poverty, family disruption or forced early marriage. Previous research in slum areas of Ethiopia suggests that a large number of migrant females are absorbed into domestic work, frequently living in the household in which they work. 15

\section{Data Collection}

In each of the three cities, two kebeles (the smallest administrative unit in Ethiopia) were selected. Because the study served as the baseline survey for a planned HIVprevention project for out-of-school females, one of the kebeles would eventually serve as the intervention area for the study, and the other kebele would serve as control. Both the intervention and control kebeles were selected from the poorest areas of the cities, and were comparable in terms of the socioeconomic status and ethnic and religious composition of the population. However, control kebeles were not contiguous with intervention kebeles. Within the study areas of each city, 24 enumeration areas (12 in each kebele) were selected at random, with the assistance of the Ethiopia Central Statistical Agency.

In the first stage of the study, a census of the households in the enumeration areas was conducted. All household members were listed, along with their age, sex and relationship to the household head. Researchers suspected underreporting of resident domestic workers in previous population-based studies of adolescents. Therefore, the household listing included a special probe asking about usual members of the household, who may include domestic workers or other nonfamily members. This list of residents served as the sampling frame from which respondents were selected for the study. In each urban center, 666 households with out-of-school female adolescents aged 10-19 were selected for inclusion in the study. As the baseline for an intervention study, the sample size was calculated to detect an eight-percentage-point change in a hypothetical variable measuring 50\% at baseline, and adjusted upward for $10 \%$ nonresponse. If a selected household had more than one respondent eligible for study, one female was selected for interview using a random number table.

Once the households were selected, trained female interviewers conducted visits to locate and interview the adolescents. If the respondent was not found at home on the initial visit, interviewers paid up to two additional visits to the household to locate her. There was no replacement of respondents who were not located. The interviewers were trained in techniques to ensure privacy during the interview process, such as conducting the interview at a distance from other people. Because the inter- 
views took place during the day, guardians were frequently away at work, making it easier to provide privacy during the interview. Respondents were not given any form of compensation or payment for their participation. In some cases, employers of domestic workers resisted allowing the interview to take place. When this occurred, the research supervisors made several visits to these households to further explain the aims of the survey. Of the 1,998 female adolescents selected for interview, 1,837 were interviewed, a response rate of $92 \%$.

Informed consent was obtained for all respondents. Among those who were younger than 18, consent was obtained from their resident parent or guardian. In addition, the study received ethical clearance from the authorized body in Ethiopia.

The questionnaire used in the study covered a broad range of topics, including household amenities and assets, education, social networks and mobility, migration, livelihoods, reproductive health knowledge and practice, marriage, births and sexual experience. The questionnaire was translated into Amharic and back-translated to ensure accuracy.

\section{Measures}

Dependent variables were sexual initiation before age 15, and nonconsensual sexual debut. The age of 14 was chosen as the cutoff for early sexual debut; a recent review suggested that those younger than 15 are generally not ready for most sexual, marital and reproductive transitions because of physiological immaturity, cognitive status and commonly held concepts of what is "old enough." ${ }^{27}$ In the interview, respondents were asked the age at which they had first had sex; responses were dichotomized into younger than 15 and 15 or older.

Respondents who reported sexual experience were asked, "What were the reasons you first had sex?" Respondents were read a series of possible motivations for initiating sex that were both coercive and noncoercive, and were asked to identify those that applied to their first sexual intercourse; multiple responses were permitted. These responses were provided in order to make the respondent feel that she was not being singled out, and to imply that the experiences are not uncommon. The motivations were: "you wanted to show love," "you were curious about it," "because you felt obliged as a spouse/partner," "because you were tricked," "because the person insisted and would not take "no' for an answer," "because the person threatened you," "because you were promised money or a gift" and "because you were physically forced." If the respondent reported trickery, insistence of a partner, threats, economic motivations or physical force as the reasons for their first sexual experience, they were coded as having nonconsensual sexual debut.* Those who reported sexual initiation motivated by love, curiosity, spousal obligation but reported no other coercive factor were considered to

*The items to measure nonconsensual sexual initiation were derived from Heise et al.'s definition of sexual coercion. ${ }^{20}$ have had consensual sexual debut.

Independent variables in this study focused on the demographic and social conditions of young women that may make them vulnerable to early or coercive sex. Variables included were educational attainment, orphanhood status, marital status, alcohol use, being a migrant to the area, being a domestic worker and social exclusion. Age difference with the first partner was initially included in the model, but was found to have too many missing cases; $29 \%$ of females did not know the age of their first sexual partner.

To measure educational attainment, respondents were asked if they had ever attended school and the highest level of schooling they had attained, collected as a continuous variable. Responses were recoded as having never attended school or having attained $1-4$ years, 5-8 years, or nine or more years of schooling for the table of sample characteristics to reflect the distribution of respondents' education. In bivariate and multivariate analysis, however, the continuous variable was used.

Orphanhood status was also recorded. Previous studies of orphans in Africa have demonstrated earlier sexual debut among young people who have lost one or both parents than among those who have two living parents. ${ }^{8,28}$ Respondents were asked if their mother and father were alive or dead, and responses to these questions were used to create a variable reflecting whether the respondents had lost at least one of their parents. Alcohol use was measured by asking if the respondent had consumed alcohol in the last three months. Marriage was measured by asking respondents if they had ever been married. In addition, a follow-up question, "Have you ever been married but later divorced?" was asked to minimize underreporting of marriage by formerly married young women.

Previous studies in urban Ethiopia have underscored the increased vulnerability to social isolation and exploitation of rural-urban migrants in low-income urban areas. ${ }^{29}$ Respondents were asked if they had ever moved from another region or from another location or district in the same region. Those reporting that they had moved from elsewhere were classified as migrants. Respondents were asked if they had ever done any work for pay and, if so, the type of work they were doing currently, or had done most recently. Respondents were coded as domestic workers (which included those who described themselves as cleaners or child-care workers) or not.

To capture social exclusion and isolation, we built a variable using a measure of friendship networks, community support and group participation. Respondents were asked how many friends they had, with a substantial proportion (56\%) reporting that they had no friends. That fewer than half of our respondents reported having friends is consistent with other studies of females in extremely poor settings, especially females whose work involves long hours and little time for recreation and socialization. ${ }^{15,30}$ To explore community support networks, two statements were read to the respondents and they were asked if they agreed or disagreed. The statements were: "If you needed money 
urgently, there is someone in your neighborhood from whom you could borrow money" and "If you didn't have a place to stay, there is someone in your neighborhood who would take you in." Finally, group participation was measured by asking respondents if they had participated in a community club or group in the last year. Respondents who reported having no friends, having no community support and not engaging in clubs or groups were coded as being socially excluded. Those with at least one friend, or who reported at least one type of community support or group participation were coded as socially included.

\section{Analysis}

Survey data were entered into the computer using CS-Pro, and converted to SPSS for analysis. The data were weighted by the number of eligible adolescent females in the household, to correct for the chance of being selected for the survey. However, in the majority of households (65\%), there was only one eligible adolescent; in $25 \%$ of households, two eligible adolescents were present. Weighted data are presented for all results except the characteristics of the sample. Sample characteristics are presented for the entire sample, and separately by sexual experience. Because the dependent variables are early sexual initiation and nonconsensual sexual debut, the sample analysis of those outcomes was restricted to females who reported sexual experience and were aged 15 or older.

Descriptive analysis was used to compare those whose sexual initiation occurred during later adolescence (ages 15-19) with those whose debut occurred during early adolescence or childhood. Likewise, we compared those who had consensual sexual debut with those who were coerced. Tests for significant differences between subgroups included chi-square tests for categorical variables and tests for continuous variables. Logistic regression was used to model the odds of early sexual debut and coerced sexual initiation.

\section{RESULTS}

\section{Sample Characteristics}

Four out of five survey respondents (81\%) were aged 15-19 (Table 1). The bias toward older ages is related to the criteria that respondents be out of school at the time of survey. Among those interviewed, 34\% had never attended formal school, $25 \%$ had had only $1-4$ years of education and $22 \%$ had had 5-8 years; $19 \%$ of respondents had nine or more years of education. Eight percent of respondents were orphans, while 29\% had lost one parent. The majority of females were migrants to the area (76\%), which is consistent with other studies of adolescents in slum areas of Ethiopia. ${ }^{29}$ Thirty-six percent of respondents were socially excluded, and $23 \%$ were sexually experienced.

\section{Characteristics of Domestic Workers}

Nearly half (48\%) of this group of poor adolescent females were performing domestic work. Sixty-nine percent of outof-school females had ever worked for pay; among those, $72 \%$ were doing or had recently done domestic work (not
TABLE 1.Percentage distribution of out-of-school females aged 10-19, by selected characteristics, according to sexual experience, Ethiopia, 2008

\begin{tabular}{|c|c|c|c|}
\hline Characteristics & $\begin{array}{l}\text { Never had sex } \\
(\mathrm{N}=1,419)\end{array}$ & $\begin{array}{l}\text { Ever had sex } \\
(\mathrm{N}=411)\end{array}$ & $\begin{array}{l}\text { All } \\
(\mathrm{N}=1,837)\end{array}$ \\
\hline \multicolumn{4}{|l|}{ Age } \\
\hline $10-14$ & 24.0 & 1.2 & 18.8 \\
\hline $15-19$ & 76.0 & 98.8 & 81.2 \\
\hline \multicolumn{4}{|l|}{ Residence } \\
\hline Addis Ababa & 36.2 & 21.7 & 32.9 \\
\hline Bahir Dar & 33.4 & 33.3 & 33.5 \\
\hline Gondar & 30.4 & 45.0 & 33.6 \\
\hline \multicolumn{4}{|l|}{ Education } \\
\hline None & 37.5 & 23.8 & 34.4 \\
\hline $1-4$ yrs. & 25.9 & 20.3 & 24.7 \\
\hline $5-8$ yrs. & 17.1 & 39.4 & 22.1 \\
\hline$\geq 9$ yrs. & 19.5 & 16.6 & 18.8 \\
\hline \multicolumn{4}{|l|}{ Orphanhood status } \\
\hline Both parents alive & 63.6 & 58.4 & 62.5 \\
\hline One parent dead & 29.6 & 28.8 & 29.4 \\
\hline Both parents dead & 6.8 & 12.8 & 8.1 \\
\hline \multicolumn{4}{|l|}{ Marital status } \\
\hline Never-married & 98.3 & 35.0 & 84.0 \\
\hline Currently married & 0.0 & 47.5 & 10.8 \\
\hline Divorced/widowed & 1.7 & 17.5 & 5.2 \\
\hline \multicolumn{4}{|l|}{ Religion } \\
\hline Orthodox Christian & 72.6 & 65.2 & 71.0 \\
\hline Muslim & 24.7 & 32.8 & 26.5 \\
\hline Other & 2.7 & 1.9 & 0.1 \\
\hline \multicolumn{4}{|l|}{ Migrant to the area } \\
\hline Yes & 78.8 & 67.6 & 76.3 \\
\hline No & 21.2 & 32.4 & 23.7 \\
\hline \multicolumn{4}{|l|}{ Domestic worker } \\
\hline Yes & 55.8 & 22.2 & 48.3 \\
\hline No & 44.2 & 77.8 & 51.7 \\
\hline \multicolumn{4}{|l|}{ Socially excluded } \\
\hline Yes & 40.5 & 22.9 & 35.8 \\
\hline No & 59.5 & 77.1 & 64.2 \\
\hline \multicolumn{4}{|c|}{ Sexually experienced } \\
\hline Yes & 0.0 & 100.0 & 22.5 \\
\hline No & 100.0 & 0.0 & 77.5 \\
\hline Total & 100.0 & 100.0 & 100.0 \\
\hline
\end{tabular}

†Ns for subgroups do not add to total because of missing data on sexual activity for seven respondents. Notes: Unweighted data. Percentages may not total 100.0 because of rounding.

shown). Other jobs held by respondents were salesgirl at a shop or kiosk ( $6 \%$ of working females), waitress or barmaid (5\%) and manual laborer (4\%). All working females worked extremely long hours; domestic workers reported an average of 63.3 hours in the previous week and those doing other paid work reported an average of 61.1 hours. However, domestic workers earned roughly half of what females in other types of work received. On average, domestic workers earned US\$8.20 in a month, compared with US $\$ 19$ per month for females in other forms of work.

Compared with other workers, domestic workers tended to have started working earlier; domestic workers began working at a mean age of 14.4 years and those performing other paid jobs began at 16.2 years. Domestic workers also 
TABLE 2. Selected characteristics of sexually experienced girls aged 15 or older, by age at first sex and context of sex

\begin{tabular}{|c|c|c|c|c|}
\hline \multirow[t]{2}{*}{ Characteristics } & \multicolumn{2}{|c|}{ Age at sexual initiation } & \multicolumn{2}{|c|}{ Context of first sex } \\
\hline & $\begin{array}{l}<15 \\
(\mathrm{~N}=147)\end{array}$ & $\begin{array}{l}15-19 \\
(\mathrm{~N}=406)\end{array}$ & $\begin{array}{l}\text { Coerced } \\
(\mathrm{N}=161)\end{array}$ & $\begin{array}{l}\text { Consensual } \\
(\mathrm{N}=392)\end{array}$ \\
\hline \multicolumn{5}{|l|}{ Residence } \\
\hline Addis Ababa & $14.3^{*}$ & 25.4 & 22.8 & 22.4 \\
\hline Bahir Dar & 33.6 & 30.5 & 33.5 & 30.4 \\
\hline Gondar & 52.1 & 44.1 & 43.7 & 47.2 \\
\hline Mean yrs. of education & $3.4^{* * *}$ & 5.6 & $4.1^{* * *}$ & 5.4 \\
\hline \multicolumn{5}{|l|}{ Orphanhood status } \\
\hline Both parents alive & $66.4^{*}$ & 56.9 & 60.6 & 58.8 \\
\hline One or both parents dead & 33.6 & 43.1 & 39.4 & 41.2 \\
\hline \multicolumn{5}{|l|}{ Marital status } \\
\hline Never-married & 28.6 & 41.4 & 53.2 & 32.0 \\
\hline Ever-married & $71.4^{*}$ & 58.6 & $46.8^{* * *}$ & 68.0 \\
\hline Consumed alcohol in last 3 mos. & 30.7 & 26.9 & 27.2 & 28.2 \\
\hline Migrant to the area & $76.4^{* *}$ & 62.8 & $75.9^{* *}$ & 62.4 \\
\hline Domestic worker & $45.7^{* * *}$ & 16.6 & $37.8^{* * *}$ & 18.6 \\
\hline Socially excluded & $35.0^{* * *}$ & 19.3 & $34.6^{* *}$ & 18.8 \\
\hline
\end{tabular}

*Differences between groups significant at $p<.05$. **Differences between groups significant at $p<.01$. ***Differences between groups significant at $p<.001$. Note: Weighted Ns.

tended to be younger, less educated, less likely to live with their parents and more likely to be migrants than those doing other forms of work. While $24 \%$ of domestic workers in the sample were aged $10-14$, only $2 \%$ of other working females were in this age-group; $49 \%$ of domestic workers had never been to school, compared with $13 \%$ of other working females. Ninety-eight percent of domestic workers had migrated to the area and $96 \%$ were not living with either parent, compared with $52 \%$ and $56 \%$, respectively, of females engaged in other forms of work. However, domestic workers were less likely to be orphaned than other females in our sample, with 33\% of domestic workers and $46 \%$ of other working females reporting having lost at least one parent.

\section{Early and Coerced Sexual Experience}

Twenty-three percent of the sample reported that they were sexually experienced, with females in Gondar (28\%) and Bahir Dar (20\%) significantly more likely to report sexual experience than those in Addis Ababa (14\%; not shown). That females in the two cities in the Amhara region exhibit higher rates of sexual experience than those in Addis Ababa may reflect the higher rates of early marriage among females in this region. Among females with sexual experience, $27 \%$ experienced debut before age 15 . Some $29 \%$ of sexually experienced females described their first sex as occurring under coercive conditions, which is consistent with other studies of nonconsensual sexual initiation. ${ }^{31,32}$ The most common forms of coercion were the partner's not taking "no" for an answer (14\%) and physical force (10\%). Other forms of coercion, trickery, threats and economic coercion, were each reported by $4 \%$ of sexually experienced females.

\section{Bivariate Analysis}

Table 2 compares selected characteristics of females for whom sexual initiation occurred before age 15 or under coercive circumstances with those for whom it did not. Females for whom sexual initiation occurred during early adolescence or under coercive circumstances had significantly less schooling than those for whom sexual initiation occurred later or under consensual conditions.

Having ever been married was associated with having had early first sex, and with not having experienced coerced first sex. Among young women who had first had sex before age $15,71 \%$ were ever-married; of those, $93 \%$ had first had sex with their spouse following marriage (not shown). Most married respondents (84\%) reported that they had first had sex out of obligation as a spouse/ partner. Being a migrant to the area and being a domestic worker were both associated with early sexual initiation and coerced sexual debut. Likewise, being socially excluded was associated with both negative outcomes. In bivariate analysis, alcohol consumption was not associated with either outcome.

\section{Multivariate Analysis}

Among sexually experienced out-of-school females aged 15 or older, educational attainment was negatively associated with the odds of first sex that was early or coerced (odds ratio 0.9 for each; Table 3). Having been married was associated with decreased odds of coerced sexual debut (0.3)

Being a domestic worker was positively associated with both negative outcomes: The odds of early sexual initiation and coerced first sex for females who worked as domestic workers were significantly higher than for other young women (3.3 and 1.8, respectively). Females who were socially excluded had odds of coerced first sex twice as high as those who were not excluded (2.0).

\section{DISCUSSION}

This study attempted to understand the social conditions-including marginalization, exclusion and exploitive labor-that may make young women more vulnerable to

\begin{tabular}{|c|c|c|}
\hline Characteristics & $\begin{array}{l}\text { Sexual } \\
\text { initiation }<15 \\
(\mathrm{~N}=521)\end{array}$ & $\begin{array}{l}\text { Coerced sexual } \\
\text { initiation } \\
(\mathrm{N}=521)\end{array}$ \\
\hline Educational attainment & $0.88(0.82-0.94)^{* * *}$ & $0.93(0.87-0.99)^{*}$ \\
\hline $\begin{array}{l}\text { Orphanhood (one or } \\
\text { both parents dead) }\end{array}$ & $0.75(0.48-1.12)$ & $0.87(0.57-1.33)$ \\
\hline Ever-married & $1.54(0.98-2.44)$ & $0.34(0.22-0.52)^{* * * *}$ \\
\hline Migrant to the area & $0.73(0.42-1.26)$ & $1.29(0.76-2.17)$ \\
\hline Domestic worker & $3.29(1.97-5.49)^{* * * *}$ & $1.77(1.08-2.92)^{*}$ \\
\hline Socially excluded & $1.10(0.66-1.82)$ & $1.99(1.23-3.23)^{* *}$ \\
\hline
\end{tabular}


early or unwanted sexual initiation. It may be that the characteristics of domestic workers increase their vulnerability. Domestic workers are dependent on their employers for survival, frequently living and working under the same roof, and earning exceedingly low salaries for long hours of hard labor. Because domestic workers are most often migrants, with few friends or relatives in the vicinity, they usually have no one to turn to for assistance or support; they may not understand or know to whom to report abuse or difficulties, and the very people they depend on for sustenance may be the ones exploiting them. The social exclusion of these workers make them easy targets for sexual abuse and exploitation, and their precarious situation, including dire poverty, means that they may be hesitant to report such incidents to authorities. Although many studies have surmised that domestic workers are more vulnerable to sexual exploitation, this is the first study, to our knowledge, that establishes that association through rigorous, quantitative methods. This study suggests that young females who are domestic workers may be more vulnerable to exploitation and abuse, including early and unwanted sex.

\section{Limitations}

This study, however, has a number of limitations. Only out-of-school females were eligible for the study; therefore, the study is not representative of all female adolescents in low-income urban areas of Ethiopia. In addition, sexual experience may be underreported, particularly in a setting such as Ethiopia, where a high value is placed on virginity until marriage. ${ }^{33}$

This study was not able to include poverty as a measure of vulnerability to early or unwanted sexual initiation. Surveys such as the Demographic and Health Surveys, as well as this survey, measure wealth or poverty at the household level. A list of household assets or amenities is read to the respondent and he or she is asked if the household possesses that amenity; responses to these questions are used to build a measure of household wealth. However, such measurement may not be applied to domestic workers, who form a large proportion of our sample. Even when a household ranks high on a wealth measure, the domestic worker who resides in that household probably does not have access to that wealth and cannot be assigned the same level of wealth or poverty as her employers. In addition, we were able to measure only cash earnings and not in-kind payments. Pay for domestic workers typically includes food or shelter, and this study was unable to measure those benefits; sporadic provision of items made reporting of such data difficult.

Finally, the fact that this study was cross-sectional limits our ability to conclude that social exclusion or engagement in domestic work results in increased vulnerability to early or coerced sexual relations. Social exclusion and work were measured at the time of the survey, not at the time of sexual initiation, making it impossible to establish a causal linkage. Reverse causality is also possible, as females who ex- perience early and unwanted sex may be excluded socially and be more likely to enter domestic service.

\section{Conclusions}

As in a number of other studies, no or low educational attainment was associated with increased odds of negative outcomes in this study. To address this risk factor, programs for female adolescents should build their social capital and inclusion, as well as provide opportunities for them to stay in school and obtain positive and nonexploitive forms of work. In Ethiopia, the Ministry of Youth and Sport and regional Youth and Sport Bureaus in Amhara region and Addis Ababa are implementing a program called "Biruh Tesfa" (Amharic for "Bright Future") in slum areas. ${ }^{34,35}$ The program combats social exclusion in these areas by providing females with groups that meet weekly with an adult female mentor. Females considered eligible for Biruh Tesfa are out-of-school slum-dwelling females aged 10-19. They are recruited by adult female mentors who go from house to house to identify eligible females, including domestic workers. Once an eligible domestic worker is identified and she shows interest in joining the program, the mentor negotiates for her participation directly with her employer.

Group meetings include basic literacy and education on HIV, reproductive health and financial literacy. In addition, females in need of medical or legal services or shelter are referred to such facilities through the program. Although there was initial skepticism among public health professionals that programs could actually reach domestic workers, the scale of Biruh Tesfa suggests that reaching socially excluded females is feasible if the appropriate strategy is used. Since Biruh Tesfa began in 2007, over 10,000 females have benefited and an evaluation of the project is currently under way.

\section{REFERENCES}

1. Ajayi A et al., Adolescent sexuality and fertility in Kenya: a survey of knowledge, perceptions and practices, International Family Planning Perspectives, 1991, 22(4):205-216.

2. Kiragu K and Zabin LS, The correlates of premarital sexual activity among school-age adolescents in Kenya, International Family Planning Perspectives, 1993, 19(3):92-97 \& 109.

3. Kirby D, Understanding what works and what doesn't in reducing adolescent sexual risk-taking, Family Planning Perspectives, 2001, 33(6):276-281

4. Jessor R, Turbin M and Costa F, Risk and protection in successful outcomes among disadvantaged adolescents, Applied Developmental Sciences, 1998, 2(4):194-208.

5. Yugo M and Davidson MJ, Connectedness within social contexts: the relation to adolescent health, Healthcare Policy, 2007, 2(3):47-55.

6. Karim AM et al., Reproductive health risk and protective factors among unmarried youth in Ghana, International Family Planning Perspectives, 2003, 29(1):14-24.

7. Kumi-Kyereme A et al., Influence of social connectedness, communication and monitoring on adolescent sexual activity in Ghana, African Journal of Reproductive Health, 2007, 11(3):133-147.

8. Hallman K, Researching the determinants of vulnerability to HIV amongst adolescents and reflecting on what it might mean for policy, IDS Bulletin, 2008, 39(5):36-44.

9. Campbell C, Williams B and Gilgen D, Is social capital a useful con- 
ceptual tool for exploring community level influences on HIV infection? An exploratory case study from South Africa, AIDS Care, 2002, 14(1):41-54

10. Hallman K and Roca E, Reducing girls' social exclusion, Promoting Healthy, Safe, and Productive Transitions to Adulthood Briefs, New York: Population Council, 2007, No. 27.

11. Hallman K and Diers J, Social isolation and economic vulnerability: adolescent HIV and pregnancy risk factors in South Africa, poster presented at the annual meeting of the Population Association of America, Boston, MA, USA, Apr. 1-3, 2004.

12. Human Rights Watch, Swept under the rug: abuses against domestic workers around the world, Human Rights Watch, 2006, Vol. 18, No. 7(C).

13. Black M, Child Domestic Workers: Finding a Voice, London: AntiSlavery International, 2002.

14. United Nations Children's Fund (UNICEF), Child domestic work, Innocenti Digest, Florence, Italy: UNICEF, 1999, No. 5.

15. Erulkar A and Mekbib T, Invisible and vulnerable: adolescent domestic workers in Addis Ababa, Ethiopia, Vulnerable Child and Youth Studies, 2007, 2(3):246-256

16. Erulkar AS et al., Differential use of adolescent reproductive health programs in Addis Ababa, Ethiopia, Journal of Adolescent Health, 2006, 38(3):253-260.

17. Jejeebhoy SJ and Bott S, Non-consensual sexual experiences of young people: a review of the evidence from developing countries, Regional Working Papers, New Delhi: Population Council, 2003, No. 16.

18. Koenig MA et al., Coerced first intercourse and reproductive health among adolescent women in Rakai, Uganda, International Family Planning Perspectives, 2004, 30(4):156-163.

19. Awusabo-Asare K and Anarfi JK, Rethinking the circumstances surrounding the first sexual experience in the era of AIDS in Ghana, The Continuing African HIV/AIDS Epidemic, 1999, pp. 9-18.

20. Heise L, Moore K and Toubia N, Sexual coercion and reproductive health: a focus on research, New York: Population Council, 1995.

21. Heise L, Ellsberg M and Gottemoeller M, Ending violence against women, Population Reports, 1999, Series L, No. 11

22. Ellsberg M et al., Researching domestic violence against women: methodological and ethical considerations, Studies in Family Planning, 2001, 32(1):1-16.

23. Lloyd CB, ed., Growing Up Global: The Changing Transitions to Adulthood in Developing Countries, Washington, DC: National Academies Press, 2005

24. Moore AM et al., Coerced first sex among adolescent girls in SubSaharan Africa: prevalence and context, African Journal of Reproductive Health, 2007, 11(3):62-82

25. Ethiopia Central Statistical Agency (CSA) and ORC Macro, Ethiopia Demographic and Health Survey, 2005, Addis Ababa, Ethiopia, and Calverton, MD, USA: CSA and ORC Macro, 2006.

26. Casacchia O, Crisci M and Reynaud C, Internal migration in Ethiopia, in: Golini A et al., Migration and Urbanization in Ethiopia, with Special Reference to Addis Ababa, Addis Ababa, Ethiopia, and Rome: CSA and Institute for Population Research-National Research Council, 2001, pp. 53-90

27. Dixon-Mueller R, How young is "too young"? Comparative perspectives on adolescent sexual, marital, and reproductive transitions, Studies in Family Planning, 2008, 39(4):247-262.

28. Thurman TR et al., Sexual risk behavior among South African adolescents: is orphan status a factor? AIDS and Behavior, 2006, $10(6): 627-635$.

29. Erulkar AS et al., Migration and vulnerability among adolescents in slum areas of Addis Ababa, Ethiopia, Journal of Youth Studies, 2006 9(3):361-374

30. Bruce J, Girls left behind: redirecting HIV interventions toward the most vulnerable, Promoting Healthy, Safe, and Productive Transitions to Adulthood Briefs, New York: Population Council, 2007, No. 23.
31. Lelissa G and Yusuf L, A cross-sectional study on prevalence of gender-based violence in three high schools, Addis Ababa, Ethiopia Ethiopian Journal of Reproductive Health, 2008, 2(1):52-59.

32. Erulkar AS et al., Adolescent Life in Low Income and Slum Areas of Addis Ababa, Ethiopia, Accra, Ghana: Population Council, 2004.

33. Molla M, Berhane Y and Lindtjørn B, Traditional values of virginity and sexual behaviour in rural Ethiopian youth: results from a cross sectional study, BMC Public Health, 2008, Vol. 8, Art. 9, <http//www. biomedcentral.com/1471-2458/8/9>, accessed Feb. 20, 2008.

34. Erulkar AS, Mekbib T and Tegegne M, Biruh Tesfa: creating a "bright future" for migrant girls in urban areas of Ethiopia, Promoting Healthy, Safe, and Productive Transitions to Adulthood Briefs, New York: Population Council, 2008, No. 21.

35. International Center for Research on Women, Integrating Multiple Gender Strategies to Improve HIV and AIDS Interventions: A Compendium of Programs in Africa, Arlington, VA, USA: John Snow, 2009.

\section{RESUMEN}

Contexto: Numerosos estudios del comportamiento sexual en adolescentes han explorado los factores asociados con la iniciación sexual temprana. Sin embargo, pocos estudios han examinado el rol de la exclusión social y la marginación en relación con la iniciación sexual temprana y no deseada.

Métodos: Se condujo un estudio poblacional de 1,837 mujeres que no asisten a la escuela, con edades entre 10-19 años, en tres áreas urbanas de bajos ingresos de Etiopía en 2008. Análisis descriptivos y multivariados fueron usados para identificar las características asociadas con haber experimentado una iniciación sexual bajo coerción y una iniciación sexual antes de los 15 años.

Resultados: Casi la mitad (48\%) de las mujeres jóvenes en la muestra eran trabajadoras domésticas, y muchas reportaron una significativa exclusión social, incluida la falta de amistades, de redes de apoyo comunitario y de pertenencia a grupos. En general, el 23\% reportó tener experiencia sexual y el 27\% de ellas tuvo su primera relación sexual antes de los 15 años. En comparación con otras mujeres jóvenes, las trabajadores domésticas tuvieron significativamente más probabilidad de haber tenido relaciones sexuales antes de los 15 años (razón de momios, 3.3); y de haber sido víctimas de coerción para tener relaciones sexuales (1.8). La exclusión social estuvo asociada con probabilidades significativamente más altas de tener una primera relación sexual bajo coerción (2.0)

Conclusiones: Los programas para mujeres adolescentes deben contribuir a construir su capital social e inclusión, asî como proporcionar oportunidades para que permanezcan en la escuela y obtengan formas de trabajo positivas y no sujetas a explotación.

\section{RÉSUMÉ}

Contexte: De nombreuses études relatives au comportement sexuel des adolescents ont examiné les facteurs associés à l'initiation sexuelle précoce. Peu se sont cependant penchées sur le rôle de l'exclusion sociale et de la marginalisation dans l'initiation sexuelle précoce et non désirée.

Méthodes: Une étude en population générale menée auprès de 1.837 jeunes filles de 10 à 19 ans hors école a été réalisée, en 2008, dans trois zones urbaines éthiopiennes à faible revenu. Les caractéristiques associées à l'initiation sexuelle vécue sous 
la contrainte ou avant l'âge de 15 ans ont été identifiées par analyses descriptives et multivariées.

Résultats: Près de la moitié (48\%) des jeunes femmes de l'échantillon étaient employées comme domestiques. Beaucoup ont fait état d'une exclusion sociale significative, exprimée par l'absence d'amis, de réseaux de soutien communautaire et d'appartenance à un groupe. Dans l'ensemble, 23\% ont déclaré être sexuellement actives, $27 \%$ d'entre elles ayant vécu leurs premiers rapports sexuels avant l'âge de 15 ans. Par rapport aux autres jeunes femmes, les domestiques se sont révélées significativement plus susceptibles d'avoir connu leurs premiers rapports sexuels avant l'âge de 15 ans (rapport de probabilités, 3,3) et d'avoir vécu des rapports sexuels sous la contrainte (1,8). L'exclusion sociale s'est avérée associée à des probabilités significativement supérieures de premiers rapports sexuels forcés $(2,0)$.

Conclusions: Les programmes destinés aux adolescentes doivent renforcer leur capital social et leur inclusion, de même que leur donner l'occasion de poursuivre leurs études et d'obtenir des formes d'emploi positives et non propices à l'exploitation.

\section{Acknowledgments}

The authors wish to acknowledge their partners from the Ethiopia Ministry of Youth and Sport and regional Youth and Sport Bureaus in Amhara and Addis Ababa. The authors thank the Central Statistical Agency for support and facilitation of data collection; Lemi Negeri and Worku Ambelu for coordination of data collection and processing; and Wendy Baldwin, Deborah Weiss and Judy Diers for their comments on earlier drafts of this article.

Author contact:aerulkar@popcouncil.org 